\title{
KOMPETENSI TENAGA ADMINISTRASI SEKOLAH TERHADAP PELAYANAN SEKOLAH SMA NEGERI 1 PADANG TUALANG KAB. LANGKAT
}

\author{
${ }^{1}$ Susanti Novita Sari, ${ }^{2}$ Dian Wahyudi, ${ }^{3}$ Seget Tartiyoso \\ Mahasiswa STKIP Budidaya Binjai \\ 1usantinovitasari624@gmail.com \\ Dosen STKIP Budidaya Binjai \\ 2diahdian88@gmail.com \\ Dosen STKIP Budidaya Binjai \\ sigittartoyoso25@gmail.com
}

\begin{abstract}
ABSTRAK
Penelitian ini bertujuan untuk mendeskripsikan bentuk kompetensi yang dimiliki oleh tenaga tata usaha sekolah di SMA Negeri 1 Padang Tualang dalam meningkatkan kualitas administrasi sekolah, serta faktor pendukung dan penghambat tenaga administrasi sekolah.Penelitian ini merupakan penelitian deskriptif yang menggunakan objek penelitian dari garis besar latar belakang historis SMA Negeri 1 Padang Tualang. Pengumpulan data dilakukan dengan berbagai wawancara dengan narasumber, kemudian dengan observasi, dan pengumpulan beberapa dokumentasi. Hasil penelitian menunjukan bahwa: 1. Upaya tenaga administrasi untuk meningkatkan kualitas administrasi sekolah di SMA Negeri 1 Padang Tualang adalah dengan a. tidak menunda pekerjaan yang sudah diberi kepada masing-masing bagian. b. memaksimalkan dalam memberikan pelayanan yang baik terhadap guru, karyawan dan peserta didik. c. menjalin hubungan kerjasama dengan pemerintah dan lembaga-lembaga masyarakat. d. menjaga dan memelihara barang-barang dan alat-alat inventaris sekolah.2. faktor pendukungnya: terciptanya kerjasama yang baik antar staf atau karyawan, saling membantu pekerjaan antar staf, saling menciptajan suasana kerja yang harmonis antara karyawan, saling menghargai dan memahami karakter masing-masing staf atau karyawan.
\end{abstract}

Kata Kunci: Kompetensi Teknis, Tenaga Administrasi, Administrasi Sekolah.

\section{ABSTRACT}

This study aims to describe the form of competence possessed by school administrators at SMA Negeri 1 Padang Tualang in improving the quality of school administration, as well as supporting and inhibiting factors for school administration personnel. This research is a descriptive study using the object of research from an outline of the historical background. SMA Negeri 1 Padang Tualang. Data collection was carried out through various interviews with sources, then by observation, and collecting some documentation. The results showed that: 1. Administrative personnel efforts to improve the quality of school administration at SMA Negeri 1 Padang Tualang are: $a$. do not delay the work that has been assigned to each division. $b$. maximize in providing good service to teachers, employees and students. c. establish cooperative relationships with government and community institutions. $d$. maintain and maintain school inventory items and tools. 2. supporting factors: the creation of good cooperation between staff or employees, helping each other work between staff, creating a harmonious working atmosphere between employees, mutual respect and understanding the character of each staff or employee.

Keywords: Technical Competence, Administrative Personnel, School Administration. 


\section{PENDAHULUAN}

Administrasi sekolah merupakan proses keseluruhan dan kegiatan bersama yang harus dilakukan oleh semua pihak yang ada kaitannya dengan tugas-tugas. Dimana meliputi: kegiatan perencanaan, pengorganisasian, pengarahan dan pengawasan, khususnya dalam bidang pendidikan yang diselenggarakan di sekolah-sekolah. Maka perlu adanya tenaga atau personel yang handal dan mampu dalam melaksanakan kegiatan administrasi sekolah. Dengan adanya tenaga administrasi sekolah yang mampu tentu akan menunjang ketercapaian tujuan yang telah direncanakan.

Selanjutnya mutu sistem tergantung pada mutu komponen yang membentuk sistem, serta proses yang berlangsung hingga membuahkan hasil (Wahyudi, 2015:3). Tenaga administrasi sekolah harus mampu melaksanakan kegiatan-kegiatan administrasi dalam dunia pendidikan dan menguasai beberapa kompetensi yang harus dimiliki oleh tenaga administrasi sekolah. Seperti yang tercantum dalam Permendiknas No. 24 Tahun 2008 tentang Standar Tenaga Administrasi Sekolah/Madrasah, ada beberapa kompetensi yang harus dimiliki antara lain: kompetensi kepribadian, kompetensi social, dan kompetensi profesional Dari beberapa kompetensi tersebut saling berkaitan antara satu dengan lainnya. Karena tanpa salah satu kompetensi tersebut maka hasil kerja yang dihasilkan tidak akan berjalan semaksimal mungkin.

Berlangsungnya kegiatan administrasi sekolah maka unsur manusia merupakan unsur penting, karena kelancaran jalannya pelaksanaan program sekolah sangat ditentukan oleh manusia-manusia yang menjalankannya. Untuk itu personel yang bertugas menjalankan kegiatan administrasi tersebut haruslah benarbenar menguasai betul apa yang harus dilaksanakan dalam menjalankan tugas sebagai pelaksana administrasi sekolah. (Daryanto, 2005: 29)

Menurut Wahyudi (2018) beliau mengatakan bahwa administrasi pendidikan mempunyai arti sempit dan luas. Arti yang sempit dari administrasi pendidikan menyangkut pekerjaan-pekerjaan yang sifatnya surat-menyurat, mendaftarkan, membayar dan melengkapi persyaratan sesuatu.

Arti luas dalam administrasi itu berkenaan dengan menerima surat, mencatat, membuat ringkasan yang isinya untuk dibaca kepala bagian/kepala sekolah, membalas, memperbanyak, mengirim surat keluar, menyimpan atau mengarsipkan dan menyimpan dalam map/lemari tertentu. Semua urusan ini disebut juga urusan tata usaha, walaupun masih ada juga yang menggunakan istilah administrasi. Umpamanya di perguruan tinggi terdapat dua biro yang disebut Biro Administrasi Akademik dan Kemahasiswaan (BAAK) serta Biro Administrasi Umum (BAU).

The Liang Gie (1982) mengemukakan administrasi adalah segenap proses penyelenggaraan dalam setiap usaha kerjasama sekolompok orang yang mencapai tujuan tertentu. Istilah administrasi sering dipakai dalam kehidupan sehari-hari tidak saja dalam bidang pendidikan, tetapi juga dalam berbagai urusan dan kepentingan, terutama dengan kantor-kantor, mulai urusan lahir, masuk sekolah, tamat sekolah, masuk rumah sakit, cari pekerjaan, naik pangkat, urusan pensiun, dan akhirnya urusan pemakaman. (Kamars,2015: 2)

Salah satu faktor penentu keberhasilan kegiatan administrasi sekolah adalah dilihat dari seberapa besar peran tenaga administrasi 
sekolah dalam melaksanakan tugas dan tanggung jawabnya sebagai pelaksana kegiatan administrasi. Oleh karena itu tenaga administrasi sekolah perlu meningkatkan peran serta kinerja dalam melaksanakan kegiatan administrasi sekolah untuk pencapaian tujuan.

Berdasarkan penyataan diatas tenaga administrasi sekolah yang handal dan kompeten dalam bidangnya merupakan hal penting dalam pencapaian kegiatan administrasi. Karena dengan penguasaan kompetensi yang baik oleh tenaga administrasi akan sangat mendukung ketercapaian tugas pokok dan fungsi dari tenaga administrasi sekolah sesuai dengan tujuan yang ditetapkan. (Daryanto, 2005:29)

Penelitian ini bertujuan untuk mengetahui: (1) pengelolaan hubungan Masyarakat dan korelasinya dengan mutu pelayanan Pendidikan SMA Negeri 1 Padang Tualang, (2) terdapat hubungan yang positif antara hubungan masyarakat dengan mutu pelayanan Pendidikan SMA Negeri 1 Padang Tualang, (3) secara bersama-sama terdapat hubungan yang positif dan signifikan antara pengelolaan hubungan masyarakat dengan Mutu Pelayanan Pendidikan SMA Negeri 1 Padang Tualang.

Tenaga administrasi sekolah harus mampu melaksanakan kegiatan kegiatan administrasi dalam dunia pendidikan dan menguasai beberapa kompetensi yang harus dimiliki oleh tenaga administrasi sekolah. Seperti yang tercantum dalam Permendiknas No. 24 Tahun 2008 tentang Standar Tenaga Administrasi Sekolah/Madrasah, ada beberapa kompetensi yang harus dimiliki antara lain: kompetensi kepribadian, kompetensi social, dan kompetensi pedagogik. Dari beberapa kompetensi tersebut saling berkaitan antara satu dengan lainnya. Karena tanpa salah satu kompetensi tersebut maka hasil kerja yang dihasilkan tidak akan berjalan semaksimal mungkin.. Berdasarkan penjelasan diatas peneliti mengambil judul : Kompetensi Tenaga Administrasi Sekolah Terhadap Pelayanan Sekolah SMA Negeri 1 Padang Tualang Kabupaten Langkat.

\section{METODOLOGI PENELITIAN}

Penelitian ini merupakan penelitian tindakan sekolah (School Action Research), karena penelitian dilakukan untuk memecahkan masalah proses pembelajaran di sekolah. Subyek penelitian adalah orang-orang yang menjadi sumber informasi yang dapat memberikan data sesuai dengan masalah yang sedang diteliti. Adapun yang akan menjadi subyek penelitian adalah kepala sekolah dan Tata Usaha. Menurut Sugiyono (2012:144) pengertian objek penelitian adalah sebagi berikut: "Objek penelitian adalah sasaran ilmiah untuk mendapatkan data dengan tujuan dan kegunaan tertentu tentang suatu hal objektif, valid, dan realiable tentang suatu hal (variabel tertentu)". Yang menjadi objek dalam penelitian ini adalah Tata Usaha di SMA Negeri 1 Padang Tualang. Instrumen yang akan digunakan sebagai berikut: pertama : angket, Suharsimi (1995: 136-138) mengatakan angket tertutup adalah angket yang disajikan dalam bentuk sedemikian rupa sehingga responden tinggal memberikan tanda centang $(\sqrt{ })$ pada kolom atau tempat yang sesuai, kedua : wawancara dan ketiga : dokumentasi. Sugiono (2010:140) Dokumentasi merupakan catatan peristiwa yang sudah berlalu. Studi dokumentasi merupakan pelengkap/ penunjang hasil penelitian yang telah diperoleh, digunakan untuk memperoleh data atau informasi yang bersangkutan dengan SMA Negeri 1 Padang Tualang.

\section{HASIL DAN PEMBAHASAN}

Penelitian akan menganalisis temuan yang ada dan memodifikasikan teori yang ada 
kemudian membangun teori yang baru serta menjelaskan tentang implikasi-implikasi dari hasil penelitian tentang Kompetensi Tenaga Administrasi Sekolah Terhadap Pelayanan Sekolah SMA Negeri 1 Padang Tualang Kab.Langkat.

\section{Kinerja Kepala Sekolah Di SMA Negeri 1 Padang Tualang}

Dalam hal ini perencanaan ialah suatu program yang dibuat kepala sekolah untuk mencapai tujuan pendidikan, tugas kepala sekolah dalam meningkatkan kinerja guru di SMA Negeri 1 Padang Tualang. Program kepala sekolah dalam melakukan tugas dan tanggung jawab kepala sekolah.

Hasil wawancara kepada kepala sekolah mengenai tugas dan tanggung jawab kepala sekolah di SMA Negeri 1 Padang Tualang pada tanggal 16 September 2020 sebagai berikut:

"Biasanya saya bertugas memberikan bimbingan, bantuan, pengawasan dan penilaian pada masalah-masalah yang berhubungan dengan teknis penyelenggaraan dan pengembangan pendidikan pengajaran yang berupa perbaikan program dan kegiatan pendidikan pengajaran untuk dapat menciptakan situasi belajar mengajar".

Wawancara kepada kepala sekolah diatas menunjukan bahwasanya kepala sekolah melakukan perencanaan dalam kegiatan dalam mengenai tugas dan tangung jawab disekolah. Hal ini didukung dengan hasil wawancara dengan wakil kepala sekolah SMA Negeri 1 Padang Tualang pada tanggal 16 september 2020, mengenai perencanaan kompetensi tenaga administrasi sekolah:

" Dengan cara memproses memperdayakan segala sumber daya alam dan sumber daya manusia untuk mencapai siatu tujuan pendidikan yang sudah ditetapkan secara baik dan benar. Administrasi pendidikan tidak hanya menyangkut soal tata usaha sekolah, tetapi menyangkut semua kegiatan sekolah, baik mengenai kurikulum, sarana dan prasarana, perpustakaan dan lain-lain".

Wawancara kepada kepala sekolah diatas menunjukan bahwasanya kepala sekolah melakukan perencanaan dalam mengenai perencanaan tenaga administrasi sekolah. Hal ini didukung dengan hasil wawancara dengan wakil kepala sekolah SMA Negeri 1 Padang Tualang pada tanggal 16 september 2020, mengenai upaya-upaya yang dapat di lakukan untuk meningkatkan kedisiplinan di SMA Negeri 1 Padang Tualang.

"Pemberian angket kesepakatan kesediaan mematuhin aturan sekolah kepada wali murid sebagai wujud kerjasama orang tua dengan sekolah, diadakan berbagai kegiatan penunjang upaya peningkatan kedisplinan siswa dan kegiatan ekstrakulikuler, serta memberikan motivasi”.

Wawancara kepada kepala sekolah diatas menunjukan bahwasanya kepala sekolah melakukan kegiatan dalam mengenai upaya dan disiplin disekolah. Hal ini didukung dengan hasil wawancara dengan wakil kepala sekolah SMA Negeri 1 Padang Tualang pada tanggal 16 september 2020, mengenai tindakan atau solusi yang diambil dalam mengahadapi hambatan tersebut:

"Mengadakan rapat rutin setiap bulan atau pembinaan setiap kalinya untuk menyelesaikan suatu permasalahan, penggunaan saran dan prasaranan secara bergantian peryektor, pemanfaatan ruangan dengan sebaik-baiknya demi menunjang kebutuhan siswa dan kenyamanan bersama.

Wawancara kepada kepala sekolah diatas menunjukan bahwasanya kepala sekolah melakukan tindakan atau solusi yang diambil dalam mengahadapi hambatan disekolah.

\section{Kinerja Tenaga Administrasi Sekolah}

Berdasarkan Peraturan Menteri pendidikan Nasional Nomor 24 tahun 2008, standar tenaga administrasi sekolahmaka dapat 
diketahuin bahwa tugas dari tenaga administrasi sekolah adalah membantu kepala sekolah dalam melaksanakan kegiatan administrai sekolah, meliputi:

a. Melaksanakan administrasi siswa

b. Melaksanakan administrasi kepegawaian

c. Melaksanakan administrasi keuangan

d. Melaksanakan administrasi sarana prasarana

e. Melaksanakan administrasi hubungan masyarakat dan sekolah

f. Melaksanakan administrasi kurikulum

a. Tenaga Administrasi Sekolah SMA Negeri 1 Padang Tualang

Tenaga administrasi di SMA Negeri 1 Padang Tualang 10 orang. Hal ini sesuai hasil wawancara dengan Kepala Sekolah, sebagai berikut: Jumlah tenaga administrasi disekolah keseluruhan berjumlah 10 orang, peran membantu administrasi sekolah yang meliputi administrasi siswa, kepegawaian, keuangan, sarana dan prasarana, hubungan masyarakat dan sekolah, kurikulum.

1). Kompetensi teknis tenaga administrasi sekolah dalam pengelolaan kegiatan administrasi sekolah di SMA Negeri 1 padang tualang yaitu saya buat dengan mengadakan koordinasi atau rapat kerja, mengusulkan kebutuhan pegawai ke dinas terkait, dan meninjak lanjuti dengan pendayagunaan, penempatan dan penugasan tenaga administrasi sekolah meliputi pembagian tempat kerja atau lembaga, formasi jabaran, tugas pokok.

2). Kompetensi sosial tenaga administrasi sekolah dalam pengelolaan kegiatan administrasi di SMA Negeri 1 Padang Tualang yaitu yang saya buat adalah dengan mempererat tali persaudaraan, baik dalam berkomunikasi dan membangun hubungan kerja yang baik, disiplin, dan tanggung jawab.

Adapun dalam hal lain pPelaksanaan administrasi yang dilaksanakan oleh tenaga administrasi sekolah di SMA Negeri 1 Padang Tualang adalah pencatatan siswa dari awal masuk sekolah sampai siswa tersebut dinyatakan lulus dari sekolah. Dimulai dari surat pendaftaran siswa baru, daftar calon siswa baru, daftar siswa baru, pembagian kelas siswa baru, pencatatan data siswa pada buku induk, hingga data siswa yang akan menempuh UAS maupun UN dan dinyatakan lulus dari sekolah. Hal ini disampaikan oleh kepala tenaga administrasi sekolah pada hasil wawancara pada tanggal 16 September 2020 bahwa pelaksanaan administrasi sekolah yang dilaksanakan tenaga administrasi meliputi kegiatan pengadministrasian kelengkapan urusan kurikulum, membuat daftar calon peserta UAS dan UN. Pelaksanaan administrasi sekolah di SMA Negeri 1 Padang Tualang dilaksanankan dengan baik dan sesuia peraturan menteri Pendidikan Nasional Nomor 24 tahun 2008 tentang standar Tenaga Administrasi Sekolah.

Berdasarkan uraian diatas dapat disimpulkan bahwa pelaksanaan administrasi sekolah di SMA Negeri 1 Padang Tualang meliputi kegiatan pengadministrasian kelengkapan urusan tentang daftar calon peserta UAS dan UN.

\section{Kendala Kinerja Tenaga Administrasi Sekolah}

a. Kendala Internal

Kendala internal berasal dari dalam diri personil tenaga administrasi sekolah, adapun kendala yang dihadapin tenaga administrasi sekolah di SMA Negeri 1 Padang Tualang sebagai berikut:

1) Kompetensi

Kompetensi merupakan perpaduan dari pengetahuan, keterampilan, nilai, dan sikap yang direfleksikan dalam kebiasaan berfikir dan bertindak. Berdasarkan wawancara dengan wakil kepala sekolah pada tanggal 16 September 2020 menyatakan bahwa: 
"Tenaga administrasi sekolah memiliki kompetensi kepribadian yaitu karna dibawah naungan yayasan,sehingga kompetensi kepribadian setiap tenaga administrasi sudah bagus, memiliki kompetensi sosial yaitu komunikasi antar tenaga administrasi terjalin dengan baik, setiap satu bulan sekali sekolah mengadakan pengajian yang diikuti oleh seluruh pegawai sekolah.

Pernyataan yang hampir sama disampaikan oleh Kepala Tenaga Administrasi Sekolah pada hasil wawancara tanggal 16 September 2020 sebagai berikut:

"Ya, kompetensi kepribadian yang dimiliki berupa adanya rasa bertanggung jawab dengan pekerjaanya dan saling mengerti antara saya dan tenaga administrasi membuat lingkungan kerja dibagian tenaga administrasi dapat berjalan dengan baik, kompetensi sosial yang dimiliki berupa hubungan komunikasi saya dan tenaga administrasi terjalin baik dan kegiatan pengajian rutin yang diadakan sekolah setiap satu bulan sekali diikuti oleh semua pegawai sekolah, kompetensi teknis yang dimiliki berupa kompetensi teknis yang saya miliki dapat dibuktikan dengan mengikuti beberapa pelatihan dan kompetensi yang berupah menyelesaikan pekerjaan administrasi sekolah yang sudah saya jalani, sehingga pekerjaan administrasi sekolah sudah seperti hal biasa.

b. Kendala Eksternal

Berdasarkan hasil observasi/ pengamatan pada tanggal 16 September 2020 yang dapat dimiliki oleh sekolah pada bagian kantor administrasi sekolah sudah cukup memadai, diantaranya adanya komputer, printer, meja, lemari untuk menyimpan dokumentasi sekolah, kipas angina, dll. Sarana tersebut dimanfaatkan oleh tenaga administrasi sekolah dengan baik, berdasarkan narasumber diatas dan hasil observasi dapat disimpulkan bahwa sarana yang dimiliki di kantor tenaga administrasi sekolah tidak mengalami kendala dalam kelengkapan sarana maupun kebermanfaatan sarana yang ada.

\section{Solusi Dalam Menghadapi Kendala Tenaga Administrasi Sekolah}

a. Kendala Internal

Hal yang disampaikan oleh Kepala Tenaga Administrasi Sekolah dari hasil wawancara pada tanggal 16 September 2020 menyatakan bahwa: "Kendala internal yang ada, jam kehadiran tenaga administrasi sekolah yang seharusnya jam 07.00 tetapi ada beberapa tenaga administrasi yang tidak dating tepatwaktu, dikarenakan ada kesibukan lain di pagi hari di rumah. Solusinya dengan mendiskusikan dengan tenaga administrasi yang lain, agar tidak ada rasa iri, dan alhamdullilah teman-teman yang lain akan hal itu".

b. Kendala Eksternal

Hal yang disampaikan oleh Kepala Tenaga Administrasi Sekolah dari hasil wawancara pada tanggal 16 September 2020 menyatakan bahwa: "Kendala eksternal yaitu muncul dari peraturan pimpinan daerah untuk batas usia pegawai tenaga administrasi maksimal 65 tahun, tetapi karena susah mencari pengganti pegawai honorer, sehingga solusinya pihak sekolah mengkomunikasikan terhadap pimpinan daerah agar sekolah tidak kekurangan pegawai administrasi sekolah.

Jadi berdasarkan penjelasan diatas dapat disimpulkan bahwa tenaga administrasi di SMA Negeri 1 Padang Tualang, solusi untuk kendala internal maupun eksternal membutuhkan komunikasi yang baik antar pegawai tenaga administrasi sekolah maupun pimpinan daerah.

\section{KESIMPULAN}

Berdasarkan hasil penelitian dan pembahasan yang telah diuraikan sebelumnya, maka dalam penelitian ini dapat disimpulkan 
sebagai berikut:

1. Kompentensi teknis tenaga administrasi sekolah di SMA Negeri 1 Padang Tualang merupakan layanan yang berfungsi meringankan pencapaian tujuan aktivitas subtantif (pembelajaran, pekerjaan kantor yang berupa administrasi sekolah).

2. Kompetensi sosial tenaga administrasi sekolah yang berasal dari dalam diri personil tenaga administrasi sekolah, Mutu guru yang belum sesuai kompetensi yang diharapkan.

\section{DAFTAR PUSTAKA}

Daryanto. 2005. Evaluasi Pendidikan. Jakarta: Rineka Cipta.

Gie, The Liang. 1982. Administrasi Perkantoran Modern. Yogyakarta: Nurcahya.

Kamars, Dachnel. 2005. Administrasi Pendidikan Teori dan Praktek, Edisi Kedua. Padang: Universitas Putra Indonesia Press.

Permendiknas No. 24 Tahun 2008 tentang Standar Tenaga Administrasi Sekolah/Madrasah.

Sugiyono. 2010. Metode Penelitian Pendidikan Pendekatan Kuantitatif, kualitatif, dan $R \& D$. Bandung: Alfabeta.

Sugiono.2011. Metode Penelitian Pendidikan (Pendekatan. Kuantitatif, Kualitatif, dan $R \& D)$. Bandung : Alfabeta.

Suharsimi, Arikunto. 1995. Manajemen Penelitian. Jakarta :Rineka Cipta.

Wahyudi, Dian dan Ana. 2018. Administrasi Hubungan Masyarakat (Pengelolaan Hubungan Masyarakat dan Korelasinya dengan Mutu Pelayanan Pendidikan Madrasah Aliyah Swasta di Kota Binjai). Binjai: Budidaya Press.
Wahyudi, M. Dian. 2015. Hubungan Persepsi Guru Tentang Perilaku Kepemimpinan Transformasional Kepala Sekolah Dan Iklim Komunikasi Dengan Kinerja Guru SD Negeri Di Kecamatan Binjai Timur Kota Binjai. Jurnal Pendidikan dan Kepengawasan, Vol 2 No. 1, April 2015. Jurnal Pendidikan dan Kepengawasan, Vol 2 No. 1. 